\title{
Isolation of Substance P Binding Protein from Rat Brain
}

\author{
Yoshihiro Nakata, Hiroyuki Takamatsu, Naoyoshi Kuroyanagi, Hiroaki Nishio, Tomio Segawa ${ }^{1}$, \\ Toshifumi Akizawa ${ }^{2}$, Yuko Hirai ${ }^{3}$ and Mitoshi Akiyama ${ }^{3}$ \\ Department of Pharmacology, Institute of Pharmaceutical Sciences, Hiroshima University School of Medicine, \\ Kasumi 1-2-3, Minami-ku, Hiroshima 734, Japan \\ ${ }^{\prime}$ Tsuruga Women's Junior College, Tsuruga 914, Japan \\ ${ }^{2}$ Faculty of Pharmaceutical Sciences, Setsuman University, Hirakata 573-01, Japan \\ ${ }^{3}$ Department of Radiobiology, Radiation Effects Research Foundation, Hiroshima 734, Japan \\ Received February 21, 1992 Accepted April 16, 1992
}

\begin{abstract}
Substance P (SP) binding protein of rat brain was solubilized by digitonin. The solubilized proteins were then purified by sequential gel filtration, concanavalin A lectin Sepharose, and SPaffinity chromatography. The calculated molecular weight of this purified SP binding protein was $76-74$ $\mathrm{kDa}$ on sodium dodecyl sulfate-polyacrylamide gel electrophoresis. The rabbits were immunized with the purified protein and resulting polyclonal anti-sera were tested. The immune serum significantly inhibited $\left[{ }^{3} \mathbf{H}\right]$ SP binding to the 3-[(3-cholamidopropyl)dimethylammonio]-1-propane sulfonate solubilized membrane fractions from rat brain, whereas pre-bleed antiserum failed to inhibit the binding. This polyclonal antibody also inhibited the activity of ${ }^{45} \mathrm{Ca}$ influx into astroglioma cells stimulated by SP, but does not inhibit that stimulated by histamine. Furthermore, this polyclonal antibody recognized the $76-$ $74 \mathrm{kDa}$ band as assessed by Western blotting. These data strongly suggest that this polyclonal antibody could recognize a part of the natural SP receptor site.
\end{abstract}

Keywords: Substance P, Binding protein, Brain (rat), Polyclonal antibody (substance P), Affinity chromatography (substance P)

Purification and characterization of the substance $P$ (SP) receptor are important in understanding the molecular basis for the biological action between SP and its receptor. Unfortunately, there are no reports about the isolation of the SP receptor protein. However, the mRNA for the SP receptor was recently cloned and the amino acid sequence was determined (1). The molecular cloning and characterization of rat SP receptor have been reported by Hershey and Krause (2). The sequence showed the presence of $N$-glycosylation sites and hydrophobic membrane-spanning segments. The SP receptor belongs to the family of G-proteincoupled receptors and affects their functions by modulating inositol phosphate/calcium second messengers (3). The isolation of several other G-protein-coupled receptors, for example $\alpha$-and $\beta$-adrenergic receptors and muscarine receptors, has been achieved by affinity chromatography. Therefore, the present study was designed to isolate SP binding protein with carbohydrate moieties by affinity chromatography and to make a polyclonal antibody for this protein. Using the poly- clonal antibody, we could demonstrate a decrease in the SP-induced biological activity by covering the SP receptor with the polyclonal antibody.

\section{MATERIALS AND METHODS}

\section{Membrane preparation and solubilization}

Male Wistar rats $(180-250 \mathrm{~g})$ were used. Cerebral cortical membranes were prepared by the method of Nakata et al. (4). Immediately, after decapitation, the cerebral cortices were homogenized in ice-cold $0.32 \mathrm{M}$ sucrose with a glass-Teflon homogenizer. Homogenates were centrifuged at $1,000 \times g$ for 10 min to obtain the supernatants. These supernatants were then centrifuged at $17,000 \times g$ for $20 \mathrm{~min}$, and the pellets obtained were washed three times and used immediately for the solubilization experiments. For solubilization, the pellets were suspended in $50 \mathrm{mM}$ Tris- $\mathrm{HCl}$ buffer containing $1 \%$ digitonin, $100 \mathrm{mM} \mathrm{NaCl}, 10 \mathrm{mM} \mathrm{MgCl}_{2}$ and 0.1 $\mathrm{mM}$ phenylmethyl sulfonyl fluoride (PMSF) at $4^{\circ} \mathrm{C}$ for $40 \mathrm{~min}$. The final protein concentration during solu- 
bilization was approximately $5 \mathrm{mg} / \mathrm{ml}$. After centrifugation of the solubilized mixture at $100,000 \times g$ for $1 \mathrm{hr}$, the supernatant was concentrated with an Amicon Centriflo CF 25. The condensed supernatant was referred to as the digitonin-solubilized fraction.

\section{$\left.{ }^{3} H\right] S P$ binding assay}

The binding assay was performed as described previously (4). Fresh membrane preparations were suspended in assay buffer $[50 \mathrm{mM}$ Tris- $\mathrm{HCl}$ buffer $(\mathrm{pH}$ 7.4) containing $0.02 \%$ bovine serum albumin, $40 \mu \mathrm{g} / \mathrm{ml}$ bacitracin, $4 \mu \mathrm{g} / \mathrm{ml}$ leupeptin, $2 \mu \mathrm{g} / \mathrm{ml}$ chymostatin, 10 $\mu \mathrm{M}$ captopril and $\left.10 \mathrm{mM} \mathrm{MgCl}_{2}\right]$. A $50-\mu \mathrm{l}$ aliquot of $\left[{ }^{3} \mathrm{H}\right] \mathrm{SP}$ was incubated at room temperature for $30 \mathrm{~min}$ with the membrane preparation in a final volume of 500 $\mu 1$. Binding reactions were terminated by rapid filtration of the incubation mixture through a Whatman GF/B glass filter (presoaked with $0.1 \%$ polyethyleneimine). Filters were washed four times with 10 $\mathrm{ml}$ of ice-cold $50 \mathrm{mM}$ Tris-HCl buffer $(\mathrm{pH} 7.4)$. The nonspecific binding of labeled ligand was determined with $3 \mu \mathrm{M}$ unlabeled SP.

In the case of the solubilized fractions, the method was modified slightly, with the incubation time and temperature being $120 \mathrm{~min}$ and $0^{\circ} \mathrm{C}$, respectively. Filtrations were carried out using GF/B glass filters presoaked with $0.3 \%$ polyethyleneimine according to the method of Bruns et al. (5).

\section{Gel filtration}

The digitonin-solubilized fraction was applied to a column of Sephadex G $75(2.7 \times 40 \mathrm{~cm})$ previously equilibrated with $0.01 \%$ digitonin, $10 \mathrm{mM} \mathrm{MgCl}_{2}$ in 50 $\mathrm{mM}$ Tris- $\mathrm{HCl}$ buffer at $4{ }^{\circ} \mathrm{C}$. The column was eluted with the same buffer at a flow rate of $6 \mathrm{ml} / \mathrm{hr}$, and 2-ml fractions were collected. Fractions were assayed for binding activity by incubation with $1.0 \mathrm{nM}\left[{ }^{3} \mathrm{H}\right] \mathrm{SP}$ as described above.

\section{Con A-Sepharose chromatography}

The combined fractions from Sephadex G-75 chromatography were reacted batchwise with $100 \mathrm{ml}$ of concanavalin A (Con A)-Sepharose gel, which had been equilibrated with $50 \mathrm{mM}$ Tris- $\mathrm{HCl}$ buffer containing $0.01 \%$ digitonin, $10 \mathrm{mM} \mathrm{MgCl}$, and $2 \mathrm{mM} \mathrm{CaCl}_{2}$ (Con A buffer), and the gel suspension was stirred at $4^{\circ} \mathrm{C}$ for $2 \mathrm{hr}$. After washing with $500 \mathrm{ml}$ of Con A buffer, $0.2 \mathrm{M}$ $\alpha$-methylmannoside in Con A buffer was added to the gel and incubated at $4^{\circ} \mathrm{C}$ for $2 \mathrm{hr}$ to remove glycoproteins. After the incubation, the supernatant was concentrated and diluted with $50 \mathrm{mM}$ Tris- $\mathrm{HCl}$ buffer.

\section{Affinity chromatograpy}

SP was coupled to epoxy-activated Sepharose $6 \mathrm{~B}$ (Pharmacia) according to the manufacturer's directions. The eluate from the con A-Sepharose chromatography as described above was loaded batchwise by continuous shaking at $4^{\circ} \mathrm{C}$ for $2 \mathrm{hr}$ with SP-Sepharose. The gel was washed at $4^{\circ} \mathrm{C}$ with 100 volumes of $50 \mathrm{mM}$ Tris- $\mathrm{HCl}$ buffer containing $0.01 \%$ digitonin, $100 \mathrm{mM} \mathrm{NaCl}$, and $10 \mathrm{mM} \mathrm{MgCl}_{2}$. After the wash, $2 \mathrm{mM} \mathrm{SP}$ solution was added to the gel and shaken at $4^{\circ} \mathrm{C}$ for $2 \mathrm{hr}$.

Identification of glycoprotein as a SP receptor using sodium dodecyl sulfate-polyacrylamide gel electrophoresis (SDS-PAGE)

The elute from Con A-Sepharose chromatograpy was incubated with $2 \mathrm{nM} \mathrm{SP}$ at $0^{\circ} \mathrm{C}$ for $2 \mathrm{hr}$ and then covalently labeled by $50 \mu \mathrm{M}$ disuccinimidyl suberate (DSS), a bifunctional cross-linking reagent, to determine the apparent molecular weight according to a slight modification of the method of Nakata et al. (6). After the supernatant was concentrated and washed with distilled water to remove salts, the sample was lyophilized. The lyophilized material was dissolved in SDS-PAGE sample buffer ( $2 \%$ SDS, $15 \%$ glycerol, $0.0025 \%$ bromophenol blue, and $2.5 \% 2$-mercaptoethanol). Electrophoresis was performed according to the method of Lamemmli (7) using a $12 \%$ polyacrylamide slab gel. After the electrophoresis, the gel was transblotted onto a nitrocellulose filter using a Trans-Blot SD (Bio-Rad). The filter was then incubated with rabbit anti-SP antibody (500-fold final dilution) in TBS solution containing $3 \%$ gelatin at room temperature for $2 \mathrm{hr}$. After treatment, the nitrocellulose filter was stained with a Vectastain $\mathrm{ABC}$ kit.

\section{Polyclonal antibody against the SP binding protein}

The proteins eluted by acetic acid from the final SPaffinity chromatography were injected in a rabbit lymph node in the presence of Freund's adjuvant according to the method of Sigel et al. (8). To boost the antibody titers, the remaining proteins were implanted subcutaneously four weeks later, and blood was withdrawn 10 days after this treatment.

\section{${ }^{45} \mathrm{Ca}$ influx experiment}

The influx of ${ }^{45} \mathrm{Ca}$ was determined by the method of Artalejo et al. (9). In brief, U-87 MG cells were cultured for several days in Petri dishes $(50 \mathrm{~mm}$ in diameter). Before starting the influx experiment, the growth medium was removed, and the cell layer was washed with low potassium buffer that consisted of $140 \mathrm{mM}$ $\mathrm{NaCl}, 4.7 \mathrm{mM} \mathrm{KCl}, 1.2 \mathrm{mM} \mathrm{KH} \mathrm{PO}_{4}, 1.2 \mathrm{mM} \mathrm{MgSO}_{4}$, $1.2 \mathrm{mM} \mathrm{CaCl}_{2}, 11 \mathrm{mM}$ glucose and $15 \mathrm{mM}$ HEPES-Tris 
(pH 7.4). The cells were stimulated with SP or histamine in the presence of $1 \mu \mathrm{Ci}{ }^{45} \mathrm{CaCl}_{2}$, for $30 \mathrm{sec}$ at $37^{\circ} \mathrm{C}$. Cells were then washed 6 times with washing buffer $\left(140 \mathrm{mM} \mathrm{NaCl}, 4.7 \mathrm{mM} \mathrm{KCl}, 3.7 \mathrm{mM} \mathrm{MgCl}_{2}\right.$, $2 \mathrm{mM}$ EGTA, $2 \mathrm{mM} \mathrm{LaCl}, 11 \mathrm{mM}$ glucose and $15 \mathrm{mM}$ HEPES-Tris, $\mathrm{pH}$ 7.4). The radioactivity in the cells was determined in a liquid scintillation counter.

\section{Data analysis}

Significance of difference between the control and test values was determined by Student's $t$-test.

\section{Protein concentration determination}

Protein content was assayed by the method of Lowry et al. (10) with bovine serum albumin as the standard.

\section{Materials}

$\left[{ }^{3} \mathrm{H}\right]$ Substance $\mathrm{P} \quad(36.3 \mathrm{Ci} / \mathrm{mmol})$ and ${ }^{45} \mathrm{Ca} \quad(8.53$ $\mathrm{mCi} / \mathrm{mg}$ ) were purchased from NEN. Unlabeled SP was obtained from Peptide Institute, Inc. (Osaka, Japan). Bovine serum albumin, bacitracin, leupeptin, chymostatin, and Tris (hydroxymethyl)-aminomethane were purchased from Sigma (St. Louis, MO). Polyethyleneimine and $\alpha$-methyl-D-mannoside were from Nacalai Tesque, Inc. (Kyoto, Japan). Con A was from Boehringer Mannheim (Mannheim, Germany). Digitonin with a high solubility in water was from
Wako Pure Chemicals (Osaka, Japan), and all other reagents were purchased from Nacalai Tesque, Inc. (Kyoto, Japan).

\section{RESULTS}

\section{Solubilization and purification of SP binding protein}

The SP binding site was solubilized from rat brain membranes with $1 \%$ digitonin. We have reported that SP binding protein could be solubilized by 3-[(3-cholamidopropyl) dimethylammonio]-1-propane sulfonate (CHAPS) (11). The $\left[{ }^{3} \mathrm{H}\right] \mathrm{SP}$ binding activity of the CHAPS-solubilized preparations decreased to less than $20 \%$ after $10 \mathrm{hr}$ storage, even at $4^{\circ} \mathrm{C}$. In the digitoninsolubilized preparation, $\left[{ }^{3} \mathrm{H}\right] \mathrm{SP}$ binding activity was stable for at least several days at $4^{\circ} \mathrm{C}$. However, $\left[{ }^{3} \mathrm{H}\right] \mathrm{SP}$ binding activity was not observed while solubilizing proteins by $1 \%$ digitonin, but it could be detected just after the Sephadex G-75 gel permeation chromatography. This result indicates that a high concentration digitonin (in this case, $1 \%$ digitonin) interferes with the interaction of the SP receptor with $\left[{ }^{3} \mathrm{H}\right] \mathrm{SP}$.

The digitonin-solubilized and condensed fraction was applied to a Sephadex G-75 column as described in Methods. We applied $105 \mathrm{mg}$ solubilized protein $/ 7 \mathrm{ml}$ to a Sephadex G-75 column. Figure 1 shows a typical adsorption and SP binding activity profile. The activity

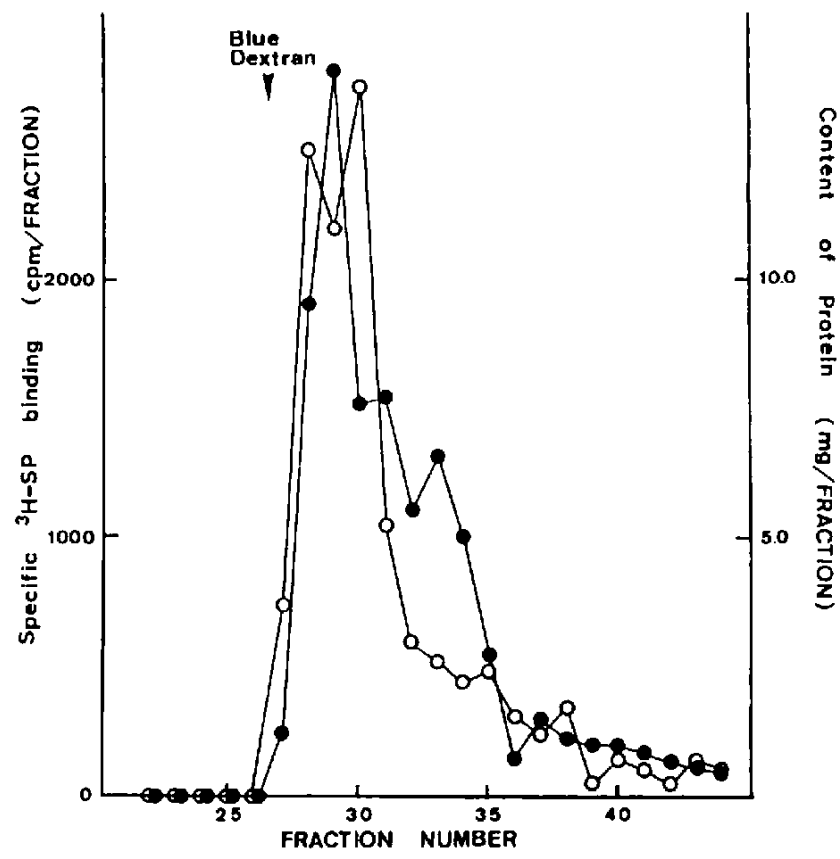

Fig. 1. Gel filtration chromatography of SP binding protein. The digitonin-solubilized fraction from rat brain was applied to the Sephadex G-75 column $(2.7 \times 40 \mathrm{~cm})$ and eluted with $50 \mathrm{mM}$ Tris-HCl buffer containing $0.01 \%$ digitonin and 10 $\mathrm{mM} \mathrm{MgCl}$. Fractions of $2 \mathrm{ml}$ were collected at a flow rate of $6 \mathrm{ml} / \mathrm{hr}$. The specific $\left[{ }^{3} \mathrm{H}\right] \mathrm{SP}$ binding activities and protein contents of these fractions were assayed. Blue dextran refers to the void volume. $O:{ }^{3} \mathrm{H}$-SP, $:$ protein. 
of $\left[{ }^{3} \mathrm{H}\right] \mathrm{SP}$ binding was broadly eluted with a void volume area. The fractions with $\left[{ }^{3} \mathrm{H}\right] \mathrm{SP}$ binding activity, usually fractions from 27 to 32 , were pooled (approximately $30 \mathrm{mg}$ protein). The combined fractions from Sephadex G-75 chromatography were mixed with Con A-Sepharose in a batchwise manner. The recovery of protein from Con A-Sepharose was approximately 1 $\mathrm{mg}$ protein, and the activity of $\left[{ }^{3} \mathrm{H}\right] \mathrm{SP}$ binding to the rat brain membranes was approximately 89 fmole. This fraction was subjected to SP-affinity chromatography. The fraction eluted from the affinity resin by the addition of $3 \mu \mathrm{M}$ SP was subjected to SDS-PAGE, and then the proteins were detected by silver staining. Under the non-reduced condition, one major band with an apparent molecular mass of $76 \mathrm{kDa}$ was present. When the sample was reduced by $50 \mathrm{mM}$ dithiothreitol, this band migrated at $74 \mathrm{kDa}$ (Fig. 2).

In the another series of experiments, to estimate the binding ability of these purified proteins, $\left[{ }^{125}{ }^{1-T y r}{ }^{8}\right] \mathrm{SP}$ was used to elute proteins from the affinity resin. After that, the eluted fraction was divided into two samples; one was added to $3 \mu \mathrm{M} \mathrm{SP}$ and the other was added to water, and both were incubated for $2 \mathrm{hr}$ at $4^{\circ} \mathrm{C}$. After the incubation, each fraction was filtered by the method described above. According to this method, purified SP

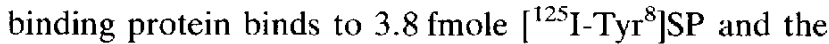
recovery of the SP binding site was $0.16 \%$. The estimated protein visualized by silver staining was approximately $0.2 \mathrm{ng}$ according to the staining density; therefore, the specific activity was $19 \mathrm{nmolc} / \mathrm{mg}$ protein. A summary of the purification of SP binding protein is shown in Table 1. An overall 1,370,000-fold purification of the SP binding protein was achieved by the three steps of different chromatographies.

\section{Immunological analysis of the SP binding protein}

In order to identify whether which protein(s) has an affinity to SP among the many glycoproteins trapped by

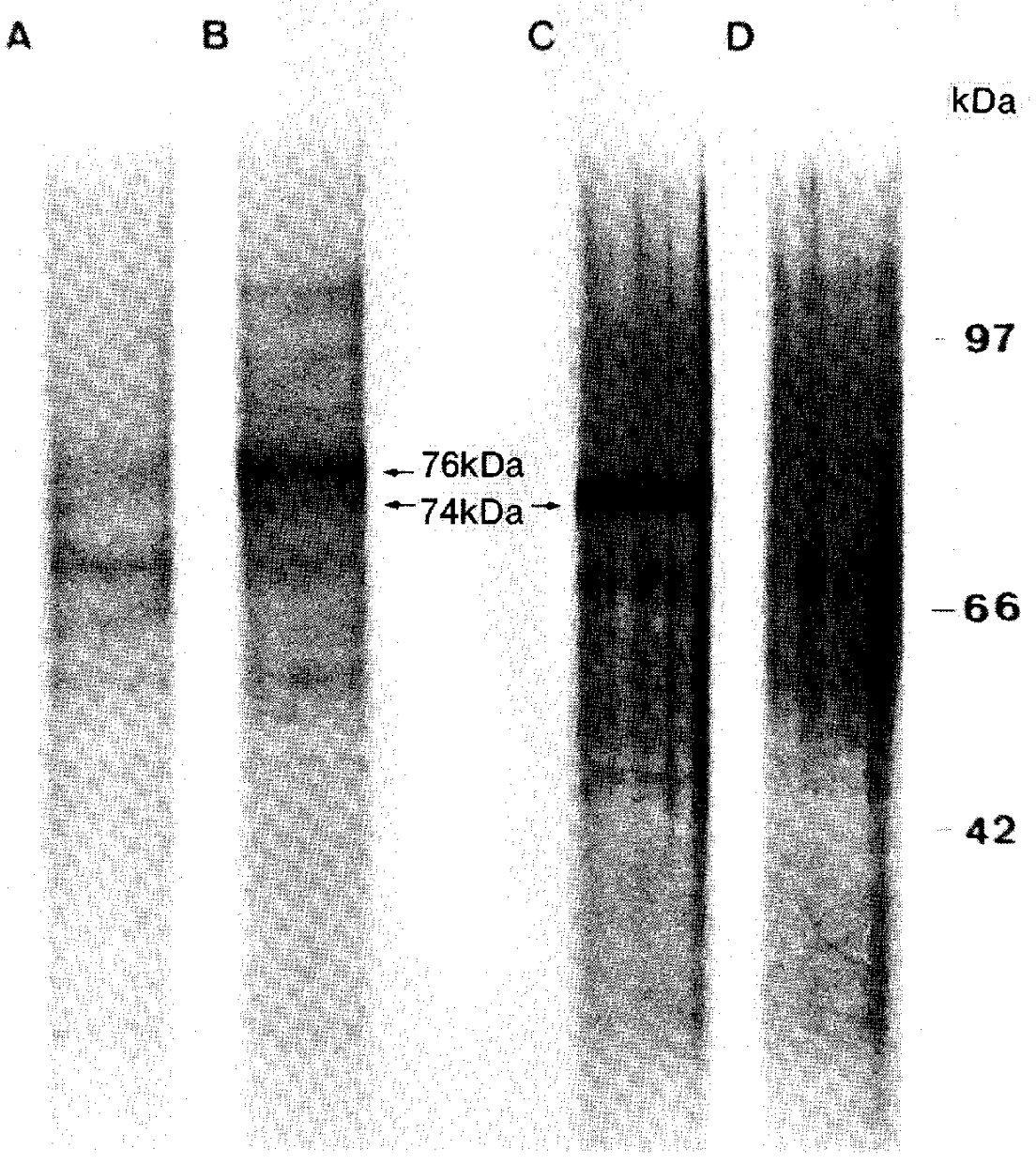

Fig. 2. Silver stain of the purified rat brain SP binding protein. SDS-PAGE analysis was performed under the reducing condition by $50 \mathrm{mM}$ dithiothreitol (C, D) and nonreducing condition (A, B). B, C: SP-Sepharose, A, D: Blank-Sepharose. 
Table 1. Purification of rat brain SP binding protein

\begin{tabular}{|c|c|c|c|c|c|}
\hline & Total protein & Total activity & Specific activity & Purification & Recovery \\
\hline & $\mathrm{mg}$ & fmole & fmole/mg & fold & $\%$ \\
\hline Membrane & $176^{\circ}$ & 2430 & 13.8 & & 100 \\
\hline Digitonin & 122 & - & - & & \\
\hline Sephadex G-75 & 30 & 171 & 5.7 & 0.4 & 7.0 \\
\hline Con A-Sepharose & 1.0 & 88.5 & 88.5 & 6.4 & 3.6 \\
\hline SP-Sepharose & $0.2^{*}$ & 3.8 & 19,000 & $1,376,00$ & 0.16 \\
\hline
\end{tabular}

${ }^{*} \mathrm{ng}$ : the protein concentration in cach band was estimated by comparing the densitometric tracing with a protein standard (bovine serum albumin) on SDS-PAGE.

Con A-Sepharose, we used DSS, a bifunctional crosslinking reagent, to make an irreversible association between the SP affinity protein(s) and SP by detecting

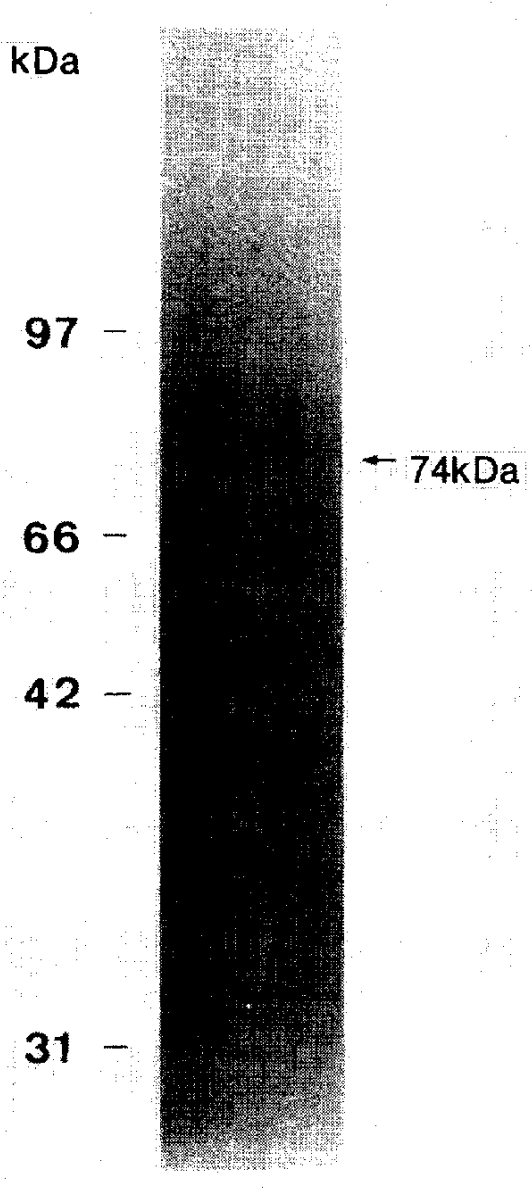

Fig. 3. Immunoblotting of rat brain SP binding protein. The Con A-Sepharose partially purified fraction was incubated with $3 \mu \mathrm{M}$ SP and crosslinked with $50 \mu \mathrm{M}$ DSS. These samples were subjected to SDS-PAGE on a $12 \%$ gel under the reducing condition, and electroblotted onto a nitrocellurose membrane. The membrane was incubated with rabbit anti-SP antibody. After the treatment, the membrane was stained with a Vectastain $\mathrm{ABC}$ kit. bound SP using anti-SP antibody as described in Materials and Methods (6). Western blotting using the anti-SP antibody showed the specific labeling of a glycoprotein with an apparent molecular weight of $74 \mathrm{kDa}$ (Fig. 3).

\section{Characteristics and properties of the anti-SP binding pro- tein antibody}

In order to further identify whether the 74-kDa glycoprotein was the SP binding protein, a rabbit was immunized with this protein, and the resulting polyclonal sera were tested by an inhibition of biological response induced by SP. First, the immune serum significantly inhibited $\left[{ }^{3} \mathrm{H}\right] \mathrm{SP}$ binding to the CHAPS solubilized fractions. At 100 dilution of the immune serum, the binding was reduced by approximately $50 \%$, while at 1,000 dilution, the reduction was about $40 \%$ (Table 2). Second, this immune serum inhibited the ${ }^{45} \mathrm{Ca}$ influx into astroglioma cell stimulated by SP. At 100 dilution of preimmune serum (blank serum), ${ }^{45} \mathrm{Ca}$ influx stimu-

Table 2. Effect of anti-SP binding protein antibody on $\left[{ }^{3} \mathrm{H}\right] \mathrm{SP}$ specific binding to the CHAPS-solubilized fractions from rat brain

\begin{tabular}{cc}
\hline Dilution & $\begin{array}{c}{\left[{ }^{3} \mathrm{H}\right] \text { SP specific binding }} \\
\text { (\% of serum blank control) }\end{array}$ \\
\hline $1: 100$ & $54.3 \pm 6.1^{* *}$ \\
$1: 1,000$ & $62.2 \pm 6.9^{*}$ \\
\hline
\end{tabular}

The CHAPS-solubilized fractions from rat brain were incubated at $0 \mathrm{C}$ for $30 \mathrm{~min}$ with various concentrations of anti-SP binding protein antibody or the serum blank. [ $\left.{ }^{3} \mathrm{H}\right] \mathrm{SP}$ binding was determined as described under Materials and Methods. Serum alone did not influence $\left[{ }^{3} \mathrm{H}\right] \mathrm{SP}$ binding. All $\left[{ }^{3} \mathrm{H}[\mathrm{SP}\right.$ values reported were calculated as a percentage of the serum blank binding value; i.e., the serum blank binding value was taken to be $100 \%$. In the same preparation, the binding assay for dopamine D-1 receptors in the presence of anti-SP binding protein, to confirm its specificity, or the serum blank was performed as described previously (17). Both sera did not have any influence on the value of $\left[{ }^{3} \mathrm{H}\right] \mathrm{SCH} 23390$ binding (98.5 $\pm 3.8 \%$ of the control at 100 -fold dilution of anti-SP binding antibody). Each value shows the mean \pm S.E.M. of five independent experiments. ${ }^{*} \mathrm{P}<0.05,{ }^{* *} \mathrm{P}<0.01$ vs. control. 
lated by $1 \mu \mathrm{M}$ SP and that by $10 \mu \mathrm{M}$ histamine were approximately $1.51 \pm 0.085$-fold $(n=4)$ and $1.69 \pm$ 0.11 -fold $(n=4)$ those of the vehicle (buffer) stimulation, respectively. The pretreatment of the immune serum (final 100 dilution) with cells for one hour at $37^{\circ} \mathrm{C}$ inhibited the accumulation of ${ }^{45} \mathrm{Ca}$ induced by 1 $\mu \mathrm{M}$ SP $(86.1 \pm 2.5 \%$ of the control, $\mathrm{n}=4)$ without any effect on histamine-induced activity $(189 \pm 18 \%$ of the control, $n=4$ ) (Fig. 4).

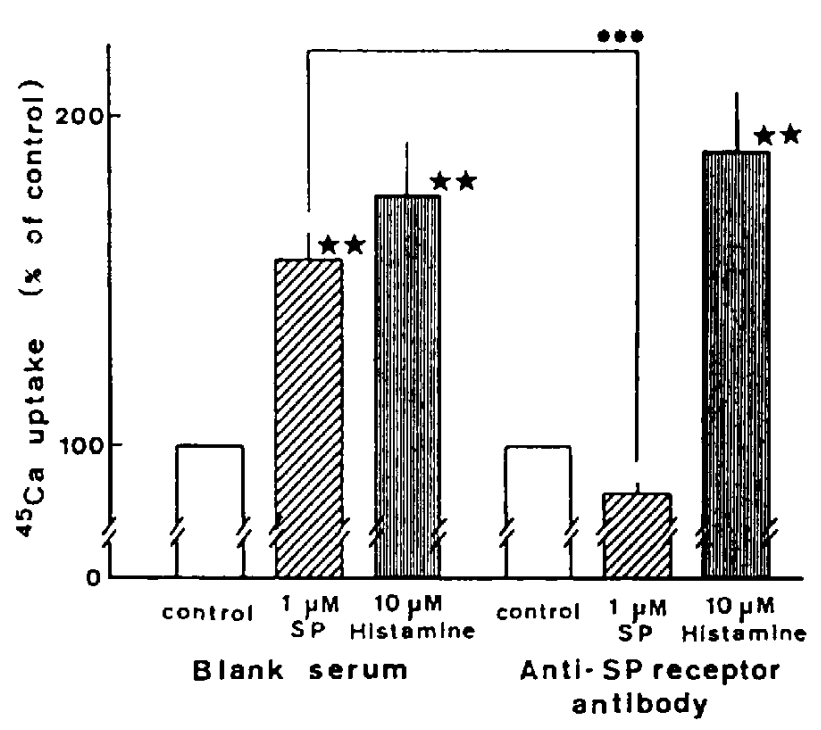

Fig. 4. Effects of anti-SP binding protein antibody on the ${ }^{45} \mathrm{Ca}$ influx into human astroglioma cells (U-87 MG) stimulated by SP or histamine. After pretreatment with anti-SP binding protein antibody for one hour at $37 \mathrm{C}$, the cells were incubated with/without $1 \mu \mathrm{M} \mathrm{SP}$ or $10 \mu \mathrm{M}$ histamine in the ${ }^{45} \mathrm{Ca}$ buffer for $30 \mathrm{sec}$ at $37^{\circ} \mathrm{C}$. The serum blank, when added to the cells kept in the low potassium buffer, had no influence on the value of ${ }^{45} \mathrm{Ca}$ influx. Pretreatment of the cells with anti-SP binding protein antibody blocked stimulation of ${ }^{45} \mathrm{Ca}$ influx by SP. Serum alone had no effect on ${ }^{45} \mathrm{Ca}$ influx, nor did it inhibit ${ }^{45} \mathrm{Ca}$ influx in response to $\mathrm{SP}$ or histamine. The value of ${ }^{45} \mathrm{Ca}$ influx in the presence of serum was defined as the control. Each point shows the mean \pm S.E.M. of $7-9$ experiments. ${ }^{\star} \mathrm{P}<0.01$ vs. control, ${ }^{* * *} \mathrm{P}<$ 0.001 vs. both sera.

\section{DISCUSSION}

In the present study, the SP binding protein from rat brain was solubilized with digitonin and then was purified with gel filtration and lectin chromatography, followed by SP affinity chromatography. We isolated 76 $\mathrm{kDa}$ material under the unreduced condition in SDSPAGE. This protein may not include GTP-binding protein(s), since GTP binding proteins can be separated from glycoproteins by Con A-Sepharose chromatography.

Many neurotransmitter receptors have now been purified. In all cases, G-protein-linked receptors have been found to be composed of single unit. Significant sequence homologies are found among all G-proteinlinked receptors, and they are translated into a conserved seven-transmembrane-spanning three-dimensional structure $(12,13)$. Another common structural feature of these receptors is related to the presence of potential $N$-linked glycosylation sites at the amino terminal (13). Glycosylation has been demonstrated to be essential to ensure the proper function and subcellular distribution of several surface glycoproteins; However, the precise role of glycosylation sites in membranebound receptors is still unknown. Our previous report demonstrated that the rat cortical SP receptor has either a biantennary complex-type or a high mannosetype of carbohydrate chain, and the carbohydrate chain is implicated in the SP binding activity of the SP receptor system (14). Similar results have recently been reported using porcine striatal membranes (15). To avoid the co-migration of other proteins which show an absent $N$-glycosylation sites like G-protein(s) in purification steps of SP binding protein, we harvested glycoproteins by lectin chromatography and estimated the molecular size of SP binding protein using DSS in these experiments (Fig. 3). Among the many glycoproteins which are trapped to Con A-Sepharose, the $76 \mathrm{kDa}$ material is SP cross-linked by DSS. Therefore, it is possible that the $76-74 \mathrm{kDa}$ glycoprotein is an SP receptor site containing various carbohydrate moieties.

The amino acid sequence of the rat SP receptor was already reported by Yokota ct al. (1). SP receptor is composed of 407 amino acids residues with a relative molecular weight of $46,346 \mathrm{Da}$. The characteristics of this amino acid sequence of the SP receptor are: 1) shares many amino acid sequence features common to the G-protein-coupled receptor superfamily, 2) possesses the two potential $\mathrm{N}$-glycosylation sites. Therefore, the molecular size of the native SP receptor should be larger than that of the protein itself. For example, the relative mobility of the striatal $\mathrm{D}_{2}$ receptors in the SDSPAGE was changed from $94 \mathrm{kDa}$ to about $43 \mathrm{kDa}$ by treating the receptors with enzymes like exo-and/or endo-glycosidase. In the present experiment, since we used Con A lectin resin to isolate glycoproteins, it is not surprising that the molecular weight of the SP receptor determined here is different from that reported by Yokota et al. (1).

Recently, Oblas et al. (16) reported that during the course of an attempt to purify the SP receptor from horse salivary glands by SP affinity chromatography, they found a $78 \mathrm{kDa}$ polypeptide that had an amino acid terminus identical to that of a glucose-regulated protein (GRP 78). This GRP 78 has no $\mathrm{N}$-glycosylation 
sites. Therefore, the $74 \mathrm{kDa}$ SP binding protein we isolated is not identical to GRP 78, even though both are eluted from SP-affinity methods.

We have successfully raised a rabbit polyclonal antibody against $76-74 \mathrm{kDa}$ SP binding protein by the intra-lymph node technique to inoculate rabbits with small quantities of antigen (8). Immunological experiments indicated that this polyclonal antibody recognized the $74 \mathrm{kDa}$ glycoprotein from rat brain, which has a high affinity to SP. This polyclonal antibody also inhibited the specific SP binding and the activity of ${ }^{45} \mathrm{Ca}$ influx into astroglioma cells stimulated by SP. These data strongly suggest that $76-74 \mathrm{kDa} \mathrm{SP}$ binding protein is a critical component of the SP receptor or the receptor itself.

To further analyze the biochemical and pharmacological characteristics of the SP receptor, it will be important to determine the amino acid sequence of this purified SP binding protein, following by the cloning of the gene encoding this protein.

\section{Acknowledgments}

This work was supported by a Grant-in-Aid for Scientific Research on Priority Area 63641005 and Grant-in-Aid (02670999) to Y.N. from the Ministry of Education, Science and Culture, Japan.

\section{REFERENCES}

1 Yokota, Y., Sasai, Y., Tanaka, K., Fujiwara, T., Tuchida, K., Sigemoto, R., Kakizuka, A., Ohkubo, H. and Nakanishi, S.: Molecular characterization of a functional cDNA for rat substance $P$ receptor. J. Biol. Chem. 264, 17649-17652 (1989)

2 Hershey, A.D. and Krause, J.E.: Molecular characterization of a functional cDNA encoding the rat substance $P$ receptor. Science 247, $958-962$ (1990)

3 Segawa, T, and Nakata, Y.: Solubilization and characterization receptors in the central nervous system. In Neuroreceptor Mechanisms in Brain, Edited by Kito, S., Segawa, T. and Olsen, R.W., p. 13-25, Plenum Press, New York (1991)

4 Nakata, Y., Tanaka, H., Morishima, Y. and Segawa, T.: Solubilization and characterization of substance $\mathrm{P}$ binding protein from bovine brainstem. J. Neurochem. 50, 522-527 (1988)
5 Bruns, R.F., Lawson-Wendling, K. and Pugsley, T.A.: A rapid filtration assay for soluble receptors using polyethylenimine treated filters. Anal. Biochem. 132, 74-82 (1983)

6 Nakata, Y., Hiraoka, C. and Scgawa, T.: Apparent molecular weight of the substance $P$ binding site in rat brain. Eur, $J$. Pharmacol. 152, $171-174$ (1988)

7 Lamemmli, U.K.: Cleavage of structural proteins during the assembly of the head of bacteriophage T4. Nature 227, $680-685(1970)$

8 Sigel, M.B., Sinha, Y.N. and VanderLaan, W.P.: Production of antibodies by inoculation into lymph nodes. Methods Enzymol. 93, 3-12 (1983)

9 Artalejo, C.R., Garcia, A.G. and Aunis, D.: Chromaffin cell calcium channel kinetics measured isotopically through fast calcium, strontium, and barium fluxe. J. Biol. Chem. 262, 915-926 (1987)

10 Lowry, O.H., Rosebrough, N.J., Farr, A.L. and Randall, R.J.: Protein measurement with the Folin phenol reagent. J. Biol. Chem. 193, 265-267 (1951)

11 Morishima, Y., Nakata, Y. and Segawa, T.: Comparision of the effects of ions and GTP on substance $P$ binding to membrane-bound and solubilized specific sites. J. Neurochem. 53, 1428-1434 (1989)

12 O'Dowd, B.F., Lefkowitz, R.J. and Caron, M.G.: Structure of the adrenergic and related receptors. Annu. Rev. Neurosci. 12, 67-83 (1989)

13 Kobilka, B.K.: The role of cytosolic and membrane factors in processing of the human $\beta_{2}$ adrenergic receptor following translocation and glycosylation in a cell-free system. J. Biol. Chem. 265, 7610-7618 (1990)

14 Takamastu, H., Tani, Y., Akiyama, M., Nakata, Y. and Segawa, T,: Characterization of the carbohydrate chain on the substance $P$ receptor in the rat brain cortex: Effect of lectins on $\left[{ }^{3} \mathrm{H}\right]$ substance $P$ binding. J. Neurochem. 56, 1452 - 1454 (1991)

15 Liu, Y.F. and Qurion, R.: Presence of various carbohydrate moieties including $\beta$-galactose and $N$-acetylglucosamine residues on solubilized porcine brain neurokinin-1/substance $P$ receptors. J. Nueochem. 57, $1944-1950$ (1991)

16 Oblas, B., Bond, N.D., Luber-Narod, J., Reyers, V.E. and Leeman, S.E.: Isolation and identification of a polypeptide in the hsp 70 family that binds substance P. Biochem. Biophys. Res. Commun. 166, 978-983 (1990)

17 Zhang, $X$. and Segawa, T.: Investigation of rat striatal dopamine D-1 receptors solubilized by digitonin with a precipitation method. Eur. J. Pharmacol. 166, $401-410$ (1989) 